\title{
Application of Terrestrial and Aerial Gravimetry in the Pimenta Bueno Graben, Brazil
}

\author{
Hans Schmidt Santos' ${ }^{1}$ Diego Moreno Monteiro², Bruno Leite Teixeira ${ }^{2}$ \\ ${ }^{1}$ Department of Research and Extension, Faculdade Salesiana Maria Auxiliadora, Macaé, Brazil \\ ${ }^{2}$ Production Engineering College, Faculdade Salesiana Maria Auxiliadora, Macaé, Brazil \\ Email: hans@on.br, diego.moreno.monteiro@gmail.com, bruno.It50@gmail.com
}

Received 5 July 2014; revised 25 August 2014; accepted 30 September 2014

Copyright (C) 2014 by authors and OALib.

This work is licensed under the Creative Commons Attribution International License (CC BY). http://creativecommons.org/licenses/by/4.0/

\section{(c) (i) Open Access}

\begin{abstract}
This paper presents an application of the gravimetric method using terrestrial and aerial data collected in one sector of the Parecis Basin, Brazil. The data received latitude and elevation corrections and also the Eotvos correction in the aerial survey case. Maps of Free-Air anomaly and Bouguer anomaly were obtained. These maps allowed us to identify the Pimenta Bueno Graben, which is an attractive region for oil and gas prospecting. Finally, the maps were compared and correlated to tectonic domains of the Pimenta Bueno Graben region.
\end{abstract}

Keywords

Gravimetric Method, Bouguer Anomaly, Parecis Basin

Subject Areas: Environmental Sciences, Geology, Geophysics

\section{Introduction}

The gravimetric method belongs to the family of potential methods. The method is able to provide useful information about the subsurface without the use of an energy source and without excavation. The method is enhanced through the use of an aircraft that can sweep large areas collecting data points with constant spacing [1]. Gravimetry is used to select the deepest areas of sedimentary basins that are more interesting for future studies in the early stages of oil and gas prospecting, as in the case of the Pimenta Bueno Graben, Brazil. This region has been the subject of intense research by the National Agency of Petroleum, Natural Gas and Biofuels (ANP) and partners due to the proven existence of active petroleum systems and exploration expectancy of unconventional gas (shale gas). The Pimenta Bueno Graben has the potential to be one of Brazil's largest reserves of this gas type that is widely exploited by the world. Data from aerial and terrestrial gravity were processed in this 
study for comparison, integration and correlation with geological and tectonic reality of the region.

\section{Characteristics of the Studied Area}

The Pimenta Bueno Graben is an extensive region (about 50,000 $\mathrm{km}^{2}$ ) located inside the Parecis Basin (Figure 1) at north of Mato Grosso state and southeast of Rondônia state in Brazil. The graben is located between the Brasnorte Horst and the Rio Branco Horst (Figure 2) [2].

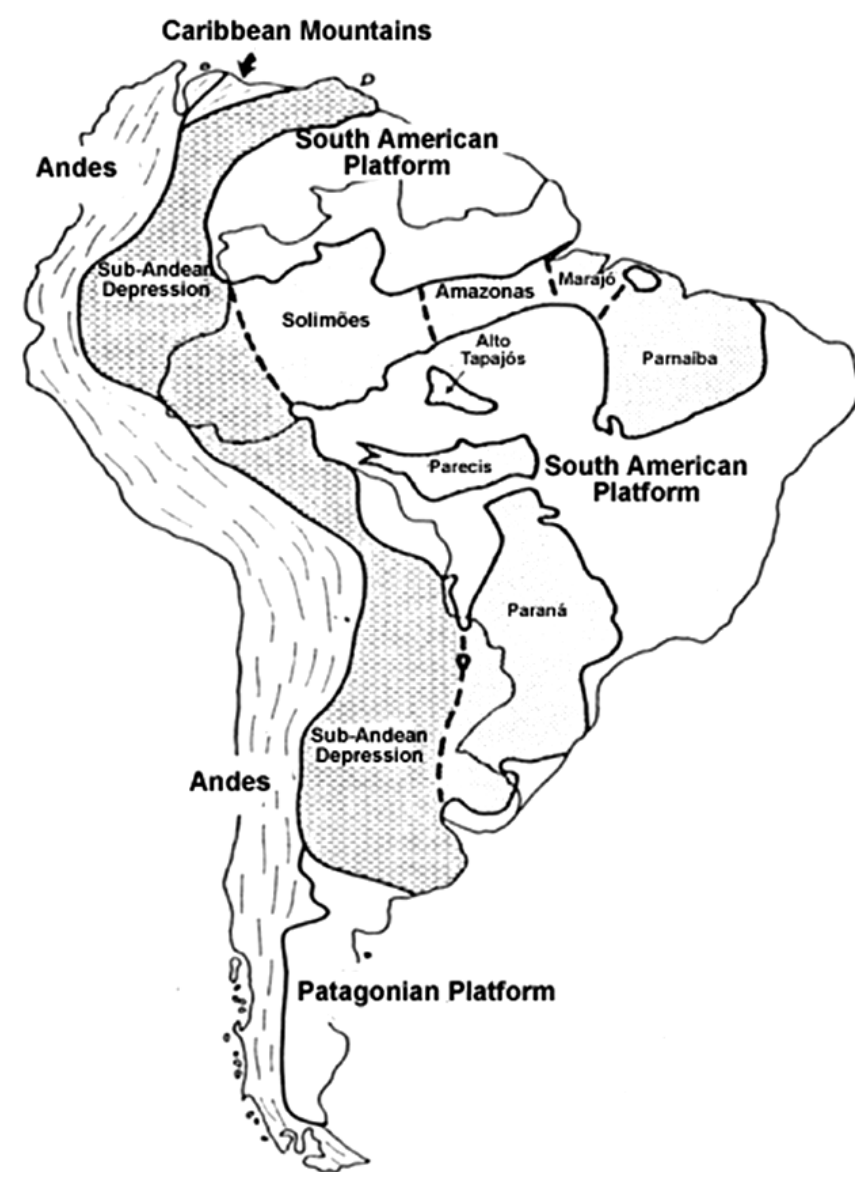

Figure 1. Location of the Parecis Basin [2].

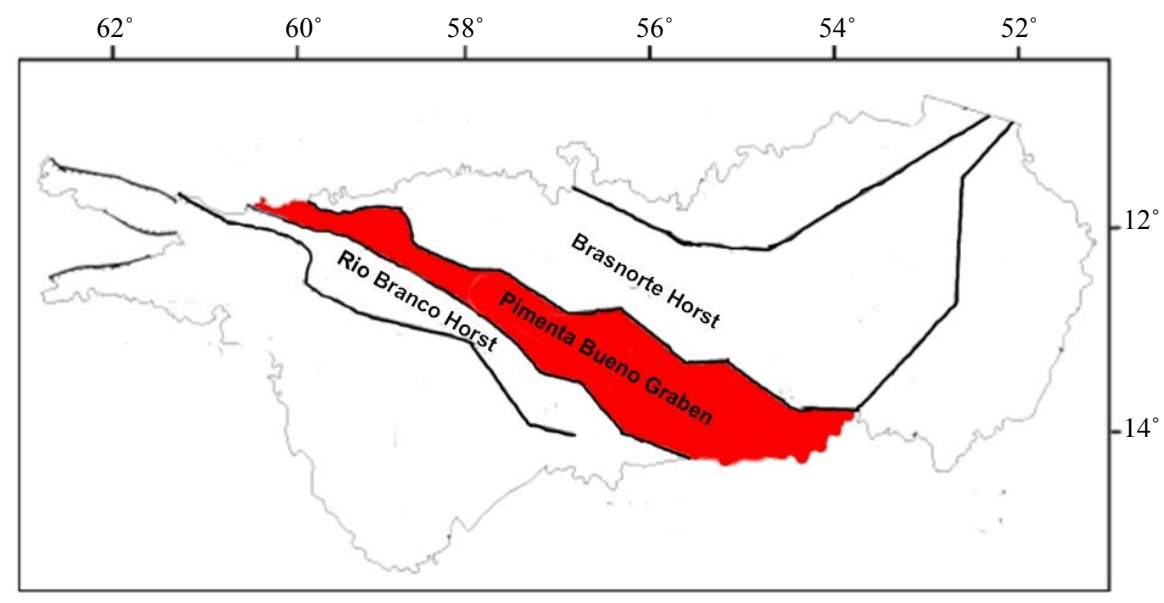

Figure 2. Location of the Pimenta Bueno Graben. 
The Parecis Basin is promoter of abrupt changes in its sediment thickness. It favors the formation of stratigraphic, structural and combined traps [3]. The geological map of the Parecis Basin (Figure 3) and the topographic map (Figure 5) spanning the graben region are shown below.

The Parecis Basin can be classified as a rift-sag basin. The basin evolution occurred from one rift basin located in the western area of the Parecis Basin whose deposits correspond to the Cacoal Formation and the Pimenta Bueno Formation that gave rise to the Pimenta Bueno and Colorado Grabens (Figure 4) [4].

The comparison of the tectonic domain map (Figure 2) to the topography map (Figure 5) shows the Pimenta Bueno Graben located in a region of the Parecis Basin with altitudes ranging from about $250 \mathrm{~m}$ up in around 500 $\mathrm{m}$.

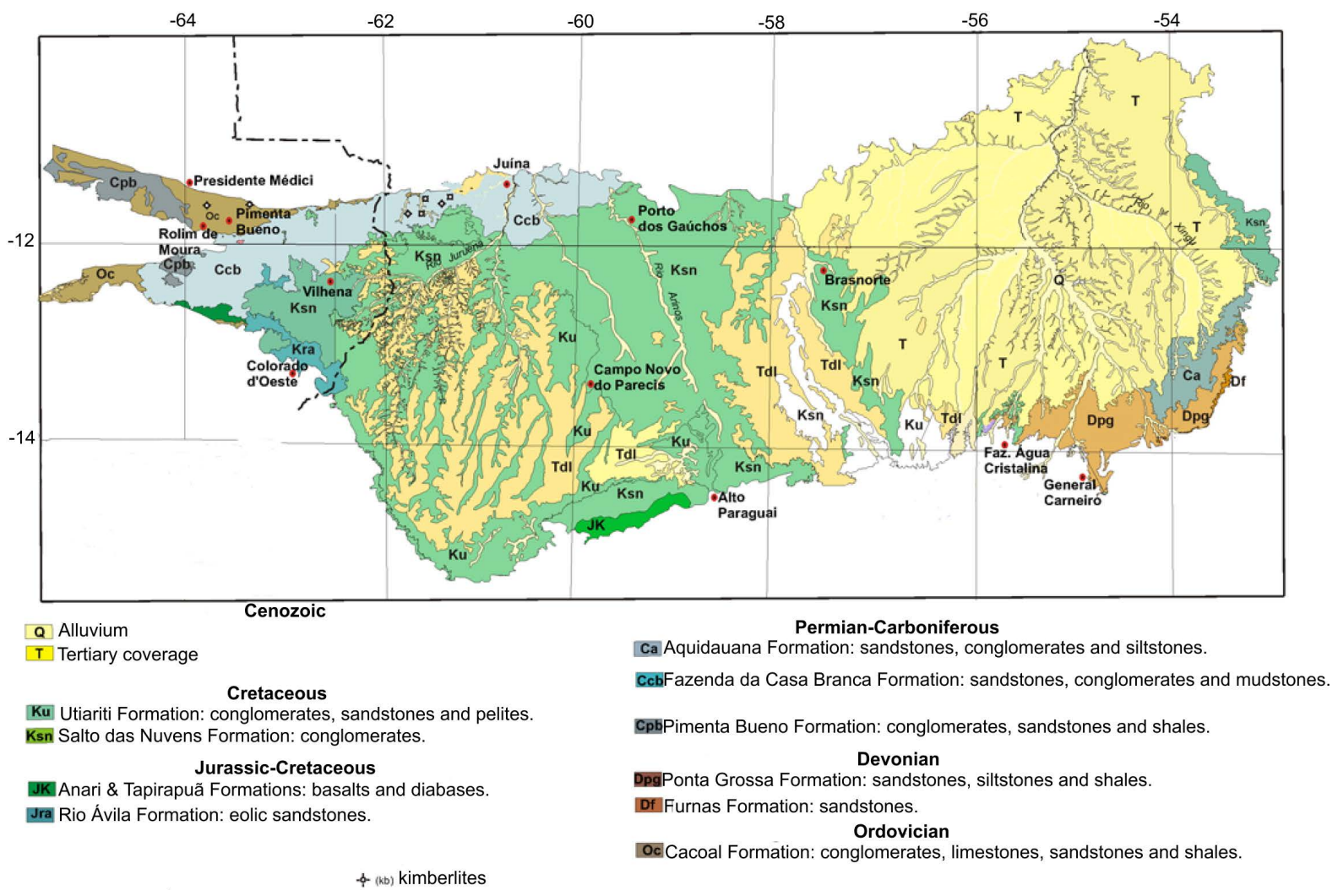

Figure 3. Geologic map of the Parecis Basin (modified from Bahia, 2007) [4].

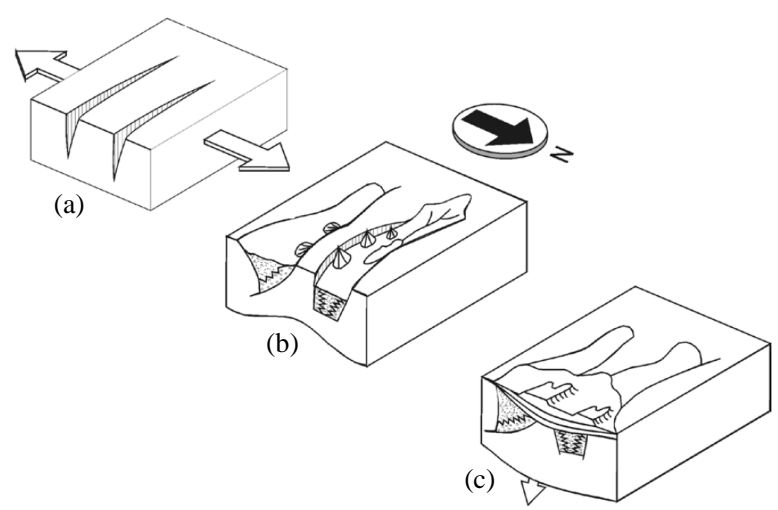

Figure 4. Evolution of the western portion of the Parecis Basin. (a) Extension in the southwest sector of the Amazonian Craton forming the Pimenta Bueno Graben and the Colorado Graben; (b) Deposition of the Cacoal Formation and the Pimenta Bueno Formation inside the grabens; (c) Rift phase end with regional subsidence and deposition of the Fazenda da Casa Branca, Rio Ávila, Anari and Parecis Formations [4]. 


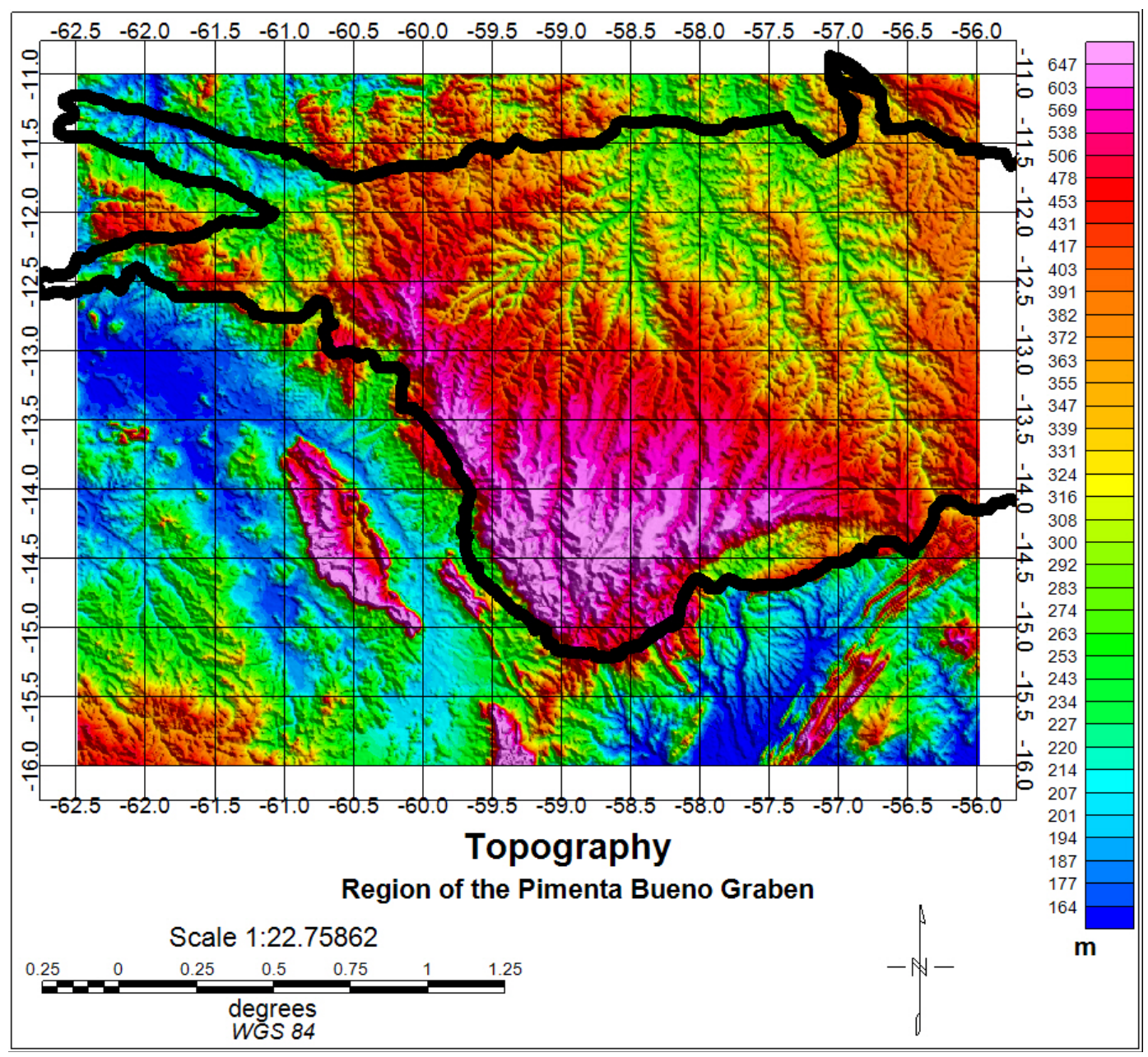

Figure 5. Topographic map of the Pimenta Bueno Graben region.

\section{Available Data}

Two gravity surveys are available. An aerial survey and a terrestrial survey were used. They cover the graben sector and surroundings.

\subsection{Juruena Project (Aerial Gravimetry)}

The gravimetric survey covering 66,982 $\mathrm{km}^{2}$ was executed in constant altitude of 1060 meters by a Dehavilland aircraft whose average speed was $200 \mathrm{~km} / \mathrm{h}$. The sampling interval was $50 \mathrm{~m}$. The flight lines were spaced 18 $\mathrm{km}$ at N20E direction and the control lines were spaced $36 \mathrm{~km}$ at N70W direction (Figure 6).

\subsection{Terrestrial Gravimetric Survey EG-31}

The terrestrial gravity data were collected by IBGE and PETROBRAS in the Parecis Basin. The gravity survey does not present a homogeneous distribution. The terrestrial gravimetry was performed only along the highways, with the highest concentration in the central portion. The spacing measure is different along the profiles (Figure 7).

\section{Method}

The gravity data are obtained using gravimeters that are positioned at ground stations or inside an aircraft. The processing of these data allows the gravimetry application by calculating the gravity anomalies that may be associated with contrasting densities of subsurface rocks. 


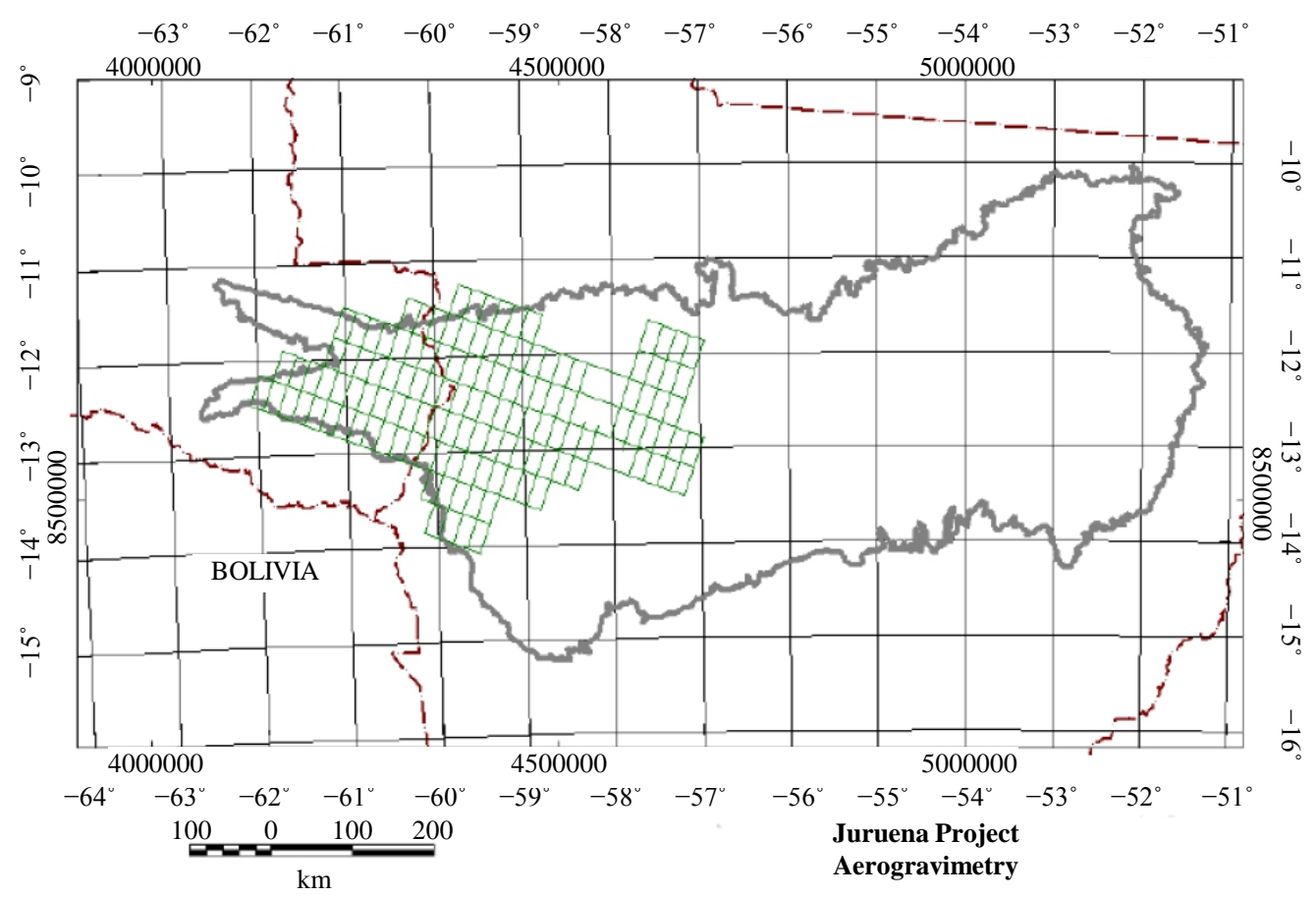

Figure 6. Juruena project (aerial gravimetry).

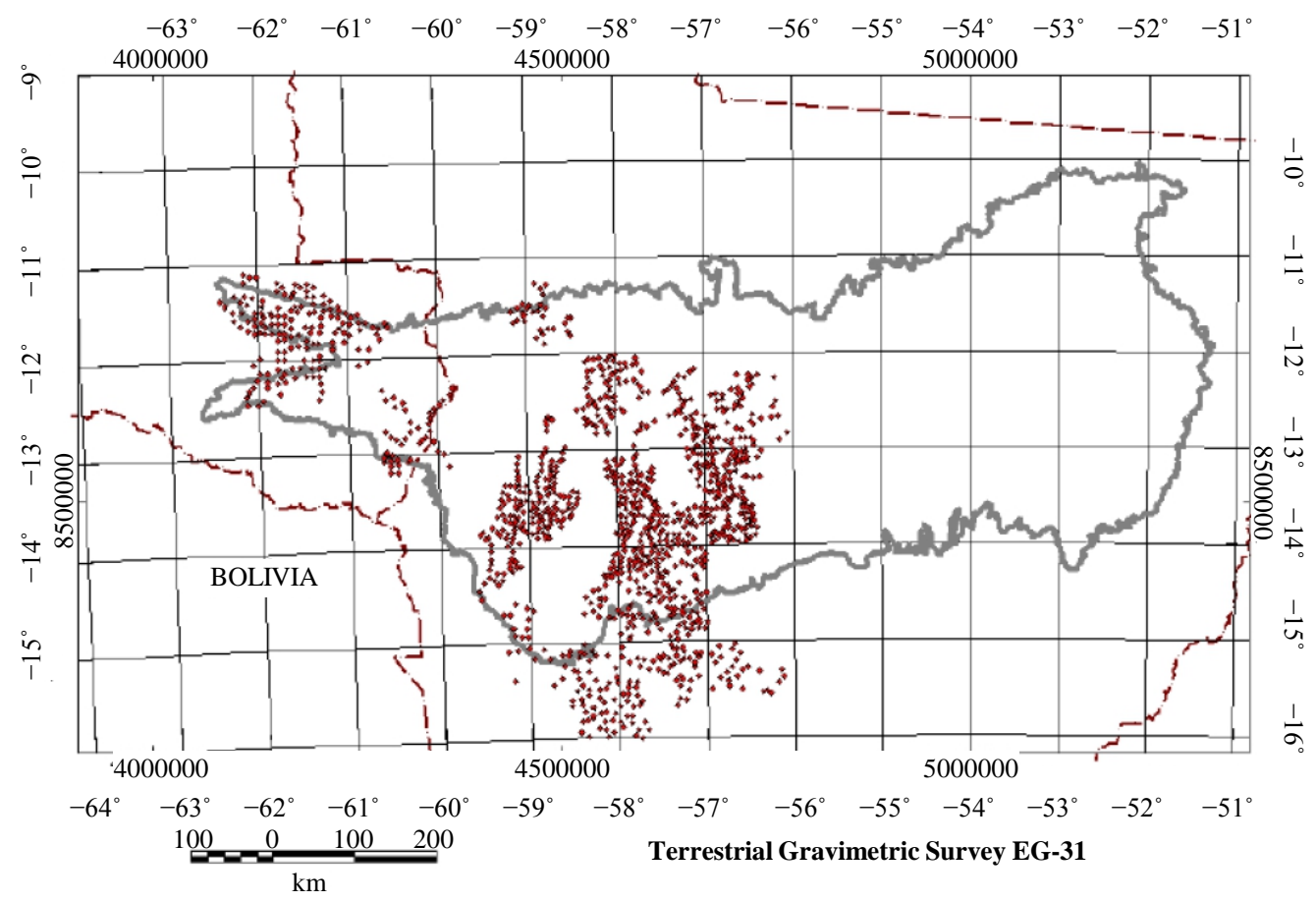

Figure 7. Terrestrial gravimetric survey EG-31.

\section{The Gravimetric Method}

The gravimetric method used to investigate the subsurface is based on measurements and interpretation of the differences in the Earth's gravitational field that result from density contrasts between rocks located on the surface and subsurface of the planet. The variations of the gravity acceleration are called gravity anomalies [5].

The Table 1 contains the computed density ranges in $\mathrm{g} / \mathrm{cm}^{3}$ for some typical rocks and minerals. 
Table 1. Approximate density ranges $\left(\mathrm{g} / \mathrm{cm}^{3}\right)$ of some common rock types and ores [1].

\begin{tabular}{|c|c|}
\hline Rocks and Ores & Density Ranges \\
\hline Alluvium (wet) & $1.96-2.00$ \\
\hline Clay & $1.63-2.60$ \\
\hline Shale & $2.06-2.66$ \\
\hline Cretaceous Sandstone & $2.05-2.35$ \\
\hline Triassic Sandstone & $2.25-2.30$ \\
\hline Carboniferous Sandstone & $2.35-2.55$ \\
\hline Limestone & $2.60-2.80$ \\
\hline Chalk & $1.94-2.23$ \\
\hline Dolomite & $2.28-2.90$ \\
\hline Halite & $2.10-2.40$ \\
\hline Granite & $2.52-2.75$ \\
\hline Granodiorite & $2.67-2.79$ \\
\hline Anorthosite & $2.61-2.75$ \\
\hline Basalt & $2.70-3.20$ \\
\hline Gabbro & $2.85-3.12$ \\
\hline Gneiss & $2.61-2.99$ \\
\hline Quartizite & $2.60-2.70$ \\
\hline Amphibolite & $2.79-3.14$ \\
\hline Chromite & $4.30-4.60$ \\
\hline Pyrrhotite & $4.50-4.80$ \\
\hline Magnetite & $4.90-5.20$ \\
\hline Pyrite & $4.90-5.20$ \\
\hline Cassiterite & $6.80-7.10$ \\
\hline Galena & $7.40-7.60$ \\
\hline
\end{tabular}

Typical sedimentary rocks (clay, shale, sandstone and limestone) have lower density compared to other rocks in petroleum systems (Table 1). This contrast can be perceived through gravimetry due to a direct relationship between observed gravity and source density by isolating the gravity anomalies. This procedure involves a series of corrections applied to the observed gravity. The following sum provides the various components of the observed gravity and the corrections in parenthesis [6]:

observed gravity $=$ attraction of the reference ellipsoid

+ effect of elevation above sea level (Free-Air)

+ effect of normal mass above sea level (Bouguer and Terrain)

+ time-dependent variations (Tidal)

+ effect of moving platform (Eotvos)

+ effect of masses that support topographic loads (Isostatic)

+ effect of crust and upper mantle density variations ("Decompensative Anomaly").

\section{Results}

The aerial and terrestrial data were processed separately. The gravity data processing was performed using the Oasis Montaj/Geosoft software. Initially, line by line investigations were carried out looking for inconsistencies. The gravity data in mGal were received with instrumental drift and tide corrections. Spectral filter was used by 
removing the wavelength of twice the maximum distance between the stations. Then, corrections (Latitude, Eotvos, Free-Air, Terrain and Bouguer) were performed and the Free-Air anomaly and Bouguer anomaly were calculated for each station and in each database.

We chose to use the bi-directional method for gridding of aerial surveys by having parallel and evenly spaced flight lines. The Kriging method was used for gridding the terrestrial survey EG-31 because it has unevenly spaced stations. The Free-Air anomaly for the aerial survey is shown in Figure 8 and the Free-Air anomaly for the terrestrial survey is shown in Figure 9.

The Free-Air anomaly map of the terrestrial survey does not cover the whole region, due to difficulties in acquiring data imposed by regions with difficult access such as forests. This difficulty was overcome by aerial survey which had a more homogeneous data distribution. However, both maps are capable of identifying regions of greatest sediment depth. The Pimenta Bueno Graben can be well located between two horsts: the Brasnorte Horst and the Rio Branco Horst.

The Bouguer anomaly is related to the subsurface density contrasts as changes in crustal thickness or the presence of sediment. In particular, the grabens and depocenters of sedimentary basins have a strong negative anomaly. The Bouguer anomaly for the aerial survey is shown in Figure 10 and the Bouguer anomaly for the terrestrial survey is shown in Figure 11.

The Bouguer anomaly has advantage over the Free-Air anomaly because it receives the Bouguer correction and the terrain correction. The Bouguer anomaly maps allowed the identification of the main tectonic structures of the region in both the aerial survey as in the terrestrial survey. The Pimenta Bueno Graben was located as a negative Bouguer anomaly ranging from $-70 \mathrm{mGal}$ to $-40 \mathrm{mGal}$ between two positive Bouguer anomaly regions that are associated with the neighbor horsts. The Colorado Graben was located as a negative Bouguer anomaly ranging from $-70 \mathrm{mGal}$ to $-30 \mathrm{mGal}$. These strong and negative anomalies were associated with the sandstones, conglomerates, limestones and shales of the Cacoal Formation and the Pimenta Bueno Formation which comprise most of the sedimentary package of the grabens according to Figure 3 and Figure 4.

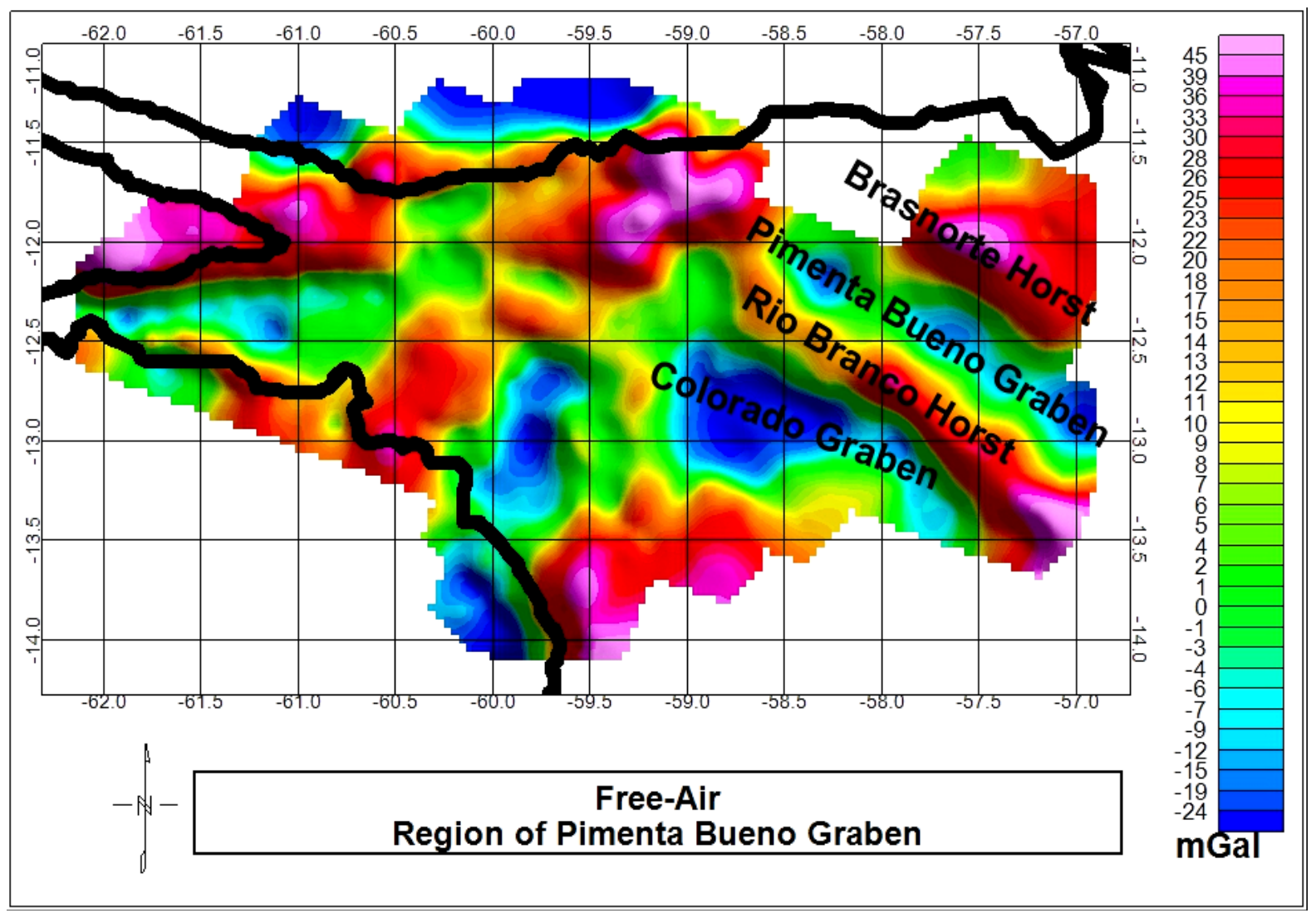

Figure 8. Free-Air anomaly for the aerial survey of the Pimenta Bueno Graben region. 


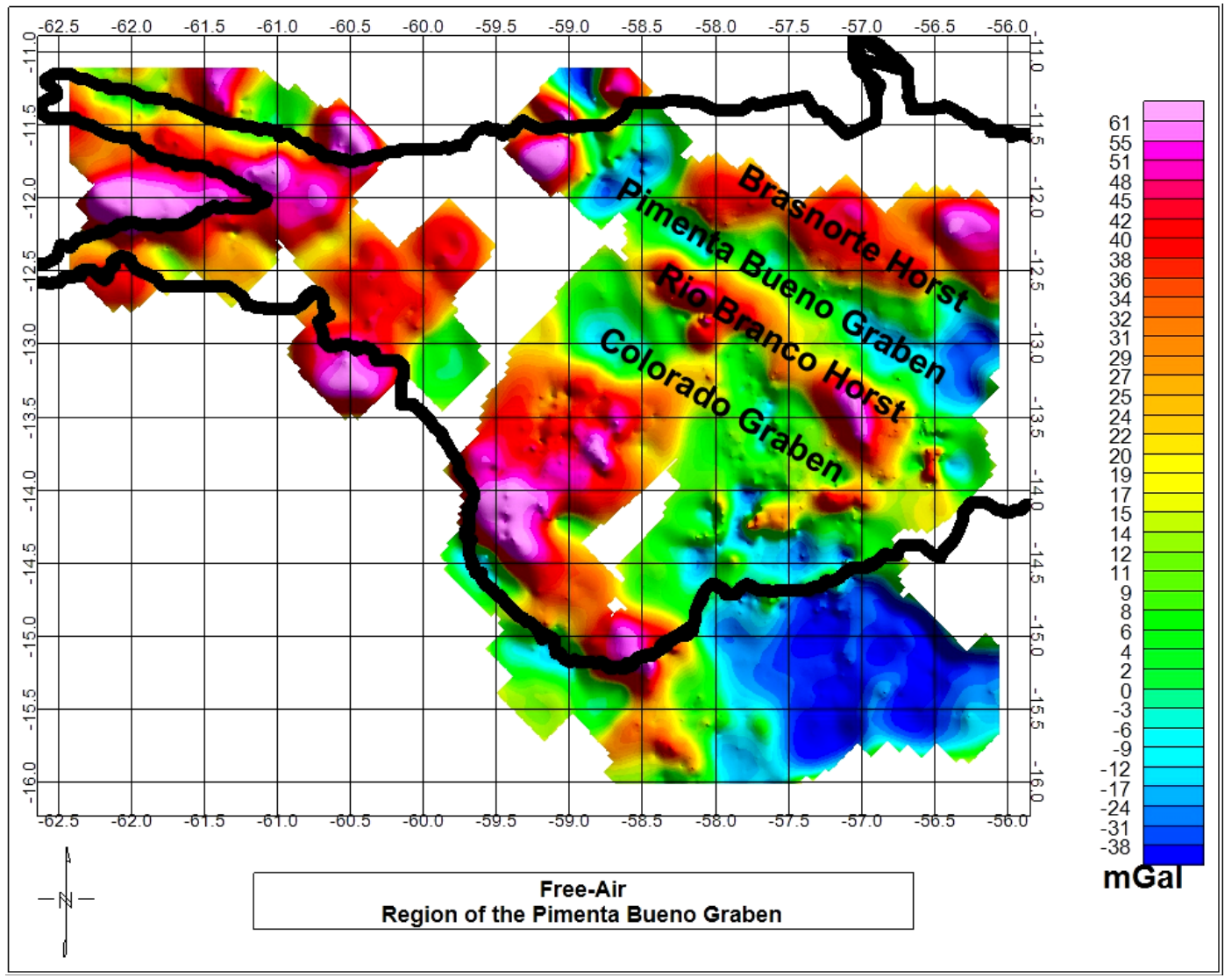

Figure 9. Free-Air anomaly for the terrestrial survey of the Pimenta Bueno Graben region.

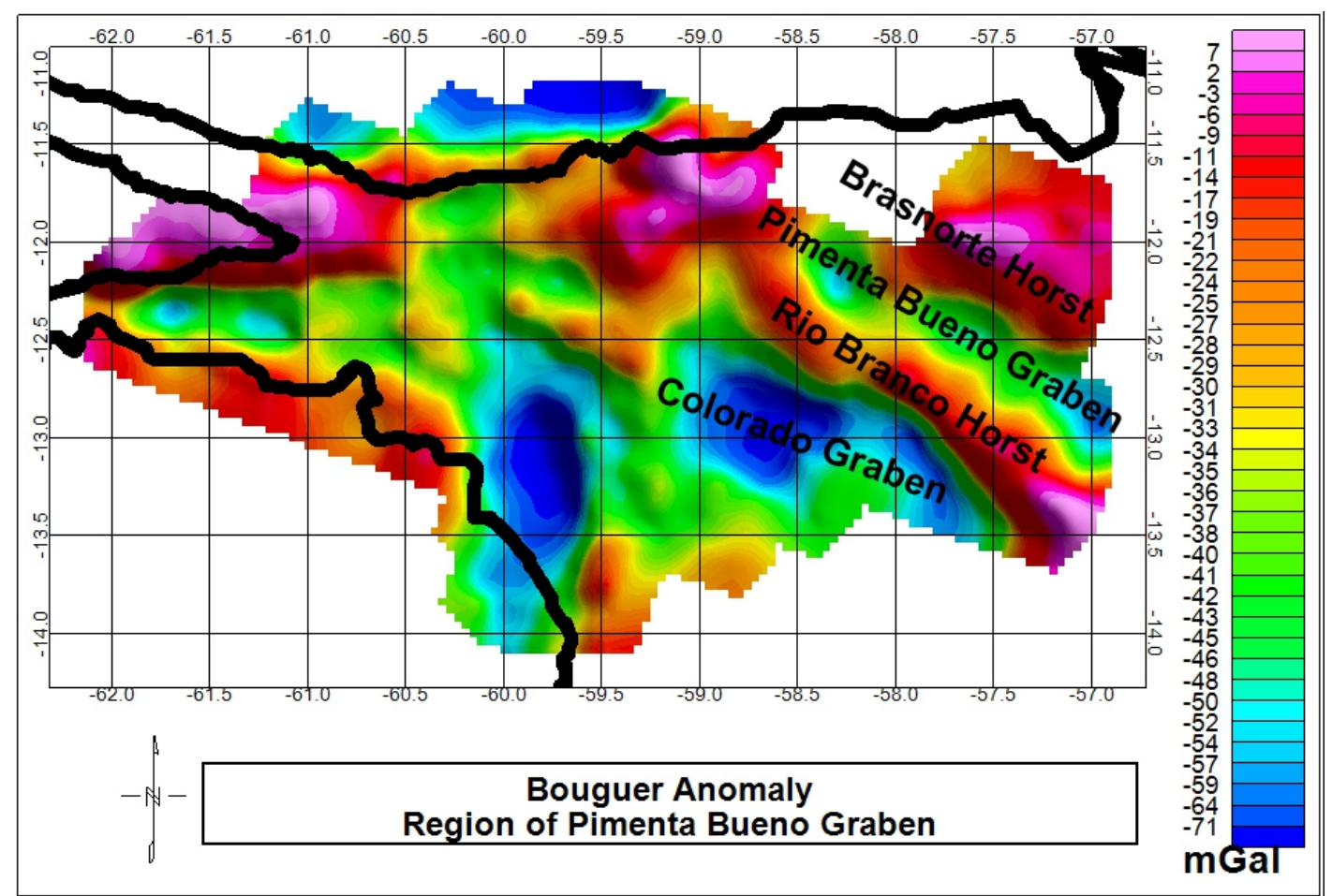

Figure 10. Bouguer anomaly for the aerial survey of the Pimenta Bueno Graben region. 


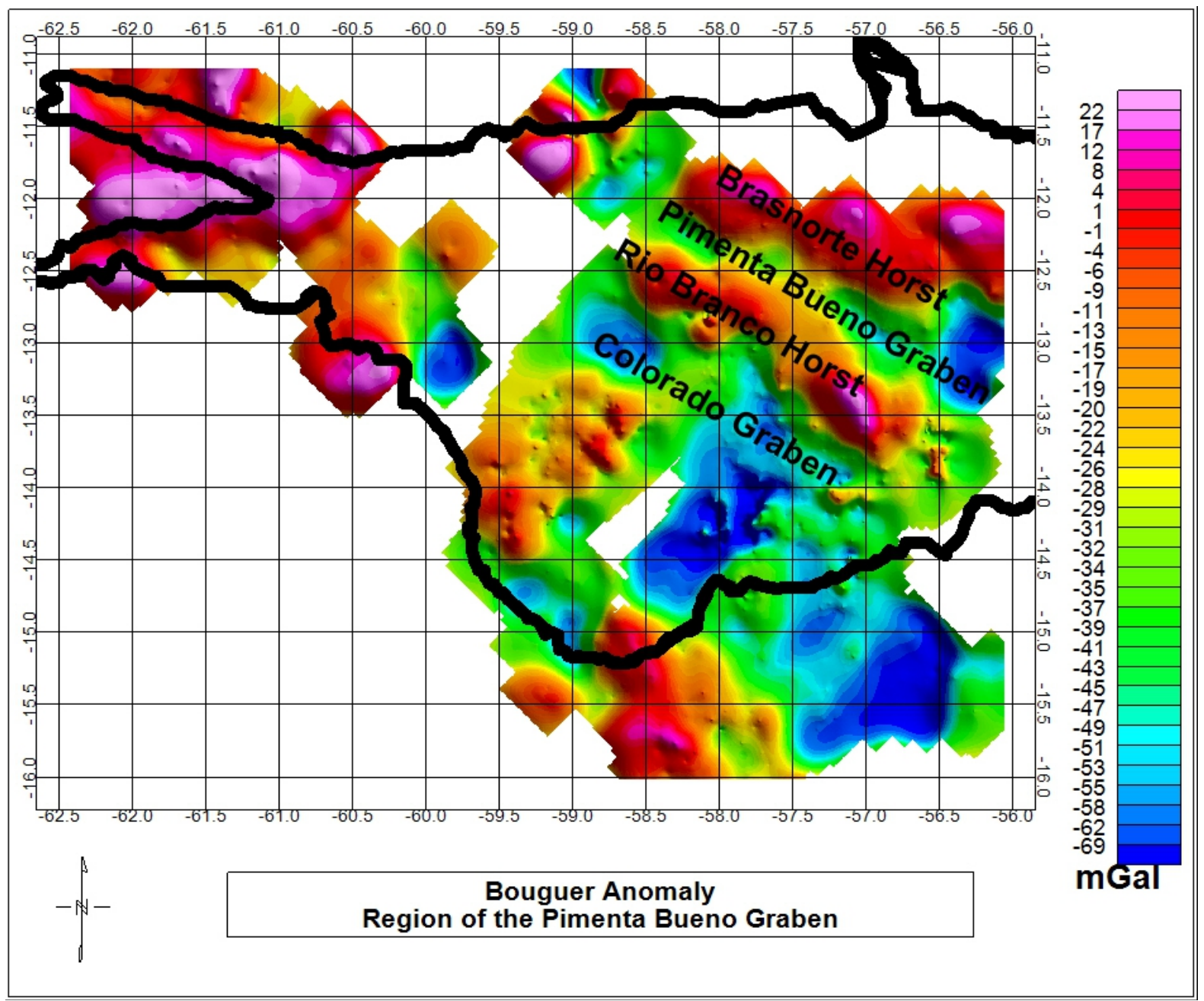

Figure 11. Bouguer anomaly for the terrestrial survey of the Pimenta Bueno Graben region.

\section{Conclusion}

The terrestrial survey had the disadvantage of not covering the whole region. Then, there was a lack of information on important regions of the basin. The aerial survey was able to overcome this difficulty with the disadvantage that the measures were carried out at altitudes of around $1 \mathrm{~km}$. However, both surveys were useful in locating the tectonic domains and they were compatible in most of the region. Both Free-Air anomaly map and Bouguer anomaly map from aerial and terrestrial surveys helped to identify the deeper regions of the Parecis Basin. A Horst-Graben region became clear. The Pimenta Bueno Graben is located between the Brasnorte Horst and the Rio Branco Horst. Finally, the application of some method of gravity inversion data is recommended for further studies. It may provide valuable information as an estimation of the basement depth.

\section{Acknowledgements}

The authors thank the reviewers for their valuable recommendations. In addition, the authors would like to express their thanks to the Research and Extension Coordinator Rodrigo S. Melo and the Engineering Production Coordinator André A. Manzela from Faculdade Salesiana Maria Auxiliadora for trusting and supporting the work.

\section{References}

[1] Kearey, P., Brooks, M. and Hill, I. (2002) An Introduction to Geophysical Exploration. 3rd Edition, Blackwell Science 
Ltd., 281 p.

[2] Santos, H.S. and Flexor, J.M. (2012) Geoelectric Directionality of a Magnetotelluric (MT) Survey in the Parecis Basin, Brazil. Revista Brasileira de Geofísica, 30, 81-92.

[3] Bizzi, L.A., Schobbenhaus, C., Vidotti, R.M. and Gonçalves, J.H. (2003) Geologia, Tectônica e Recursos Minerais do Brasil. CPRM, Brasília. (in Portuguese)

[4] Bahia. R.B.C. (2007) Tectonic Evolution of the Parecis Basin. Contribution to Earth Sciences v18. Federal University of Ouro Preto, Ouro Preto. (in Portuguese)

[5] Ernesto, M. and Ussami, N. (2002) Introdução à Geofísica. Departamento de Geofísica IAG/USP. (in Portuguese)

[6] Blakely, R.J. (1995) Potential Theory in Gravity and Magnetic Applications. Cambridge University, Cambridge. http://dx.doi.org/10.1017/CBO9780511549816 